\title{
Telocytes and Their Extracellular Vesicles-Evidence and Hypotheses
}

\author{
Dragos Cretoiu ${ }^{1,2, \dagger}{ }^{\dagger}$ Jiahong Xu ${ }^{3, \dagger}{ }^{\dagger}$ Junjie Xiao ${ }^{4, *}$ and Sanda M. Cretoiu ${ }^{1,2, *}$ \\ 1 Division of Cellular and Molecular Biology and Histology, Department of Morphological Sciences, \\ Carol Davila University of Medicine and Pharmacy, Bucharest 050474, Romania; dragos@cretoiu.ro \\ 2 Victor Babeş National Institute of Pathology, Bucharest 050096, Romania \\ 3 Department of Cardiology, Tongji Hospital, Tongji University School of Medicine, Shanghai 200065, China; \\ jhx_tj@hotmail.com \\ 4 Cardiac Regeneration and Ageing Lab, Experimental Center of Life Sciences, School of Life Science, \\ Shanghai University, Shanghai 200444, China \\ * Correspondence: junjiexiao@live.cn (J.X.); sanda@cretoiu.ro (S.M.C.); \\ Tel.: +86-21-6613-8131 (J.X.); +40-724-319277 (S.M.C.) \\ + These authors contributed equally to this work.
}

Academic Editor: Gregor Drummen

Received: 29 June 2016; Accepted: 26 July 2016; Published: 12 August 2016

\begin{abstract}
Entering the new millennium, nobody believed that there was the possibility of discovering a new cellular type. Nevertheless, telocytes (TCs) were described as a novel kind of interstitial cell. Ubiquitously distributed in the extracellular matrix of any tissue, TCs are regarded as cells with telopodes involved in intercellular communication by direct homo- and heterocellular junctions or by extracellular vesicle (EVs) release. Their discovery has aroused the interest of many research groups worldwide, and many researchers regard them as potentially regenerative cells. Given the experience of our laboratory, where these cells were first described, we review the evidence supporting the fact that TCs release EVs, and discuss alternative hypotheses about their future implications.
\end{abstract}

Keywords: telocytes; telopodes; extracellular vesicles; exosomes; ectosomes

\section{Introduction}

Living cells communicate between themselves by different modalities, which are represented by cell junctions and the cell secretion of different soluble factors. The latter can act in an autocrine, paracrine, or endocrine manner. The last decade brought in a new evolutionary concept-that cellular communication can also be mediated by the transfer of genetic information [1]. This genetic transfer (e.g., mRNA, microRNA, long non-coding RNA, and occasionally genomic DNA) is intermediated by extracellular vesicles generated and released by prokaryotic and eukaryotic cells [2]. Extracellular vesicles (EVs) are nano-sized membrane-surrounded structures originating in the endosomal compartment or shed from the plasma membrane. Classified by their size and mechanisms of biogenesis, EVs can, in general, be categorized into three classes: (a) exosomes; (b) ectosomes or shedding microvesicles; and (c) apoptotic bodies. Exosomes were discovered almost three decades ago as "cell debris", and have an endocytic origin and variable diameters between 30 and $100 \mathrm{~nm}[3,4]$. Ectosomes (also known as microvesicles) have diameters between 100 and $1000 \mathrm{~nm}$ and form by direct budding from the plasma membrane [5]. Apoptotic bodies $(50 \mathrm{~nm}-2 \mu \mathrm{m})$ are released by cells undergoing programmed cell death via outward blebbing of the apoptotic cell membrane. EVs carry receptors, bioactive lipids, proteins, and, most importantly, nucleic acids, such as mRNA, microRNA (miRNA), and non-coding RNAs. Their membrane composition (marker proteins) is particular according to the vesicle type, and their content is also variable $[4,6]$ Telocytes are no 
exception to this mode of communication, being able to release and receive different types of vesicles (Figure 1).

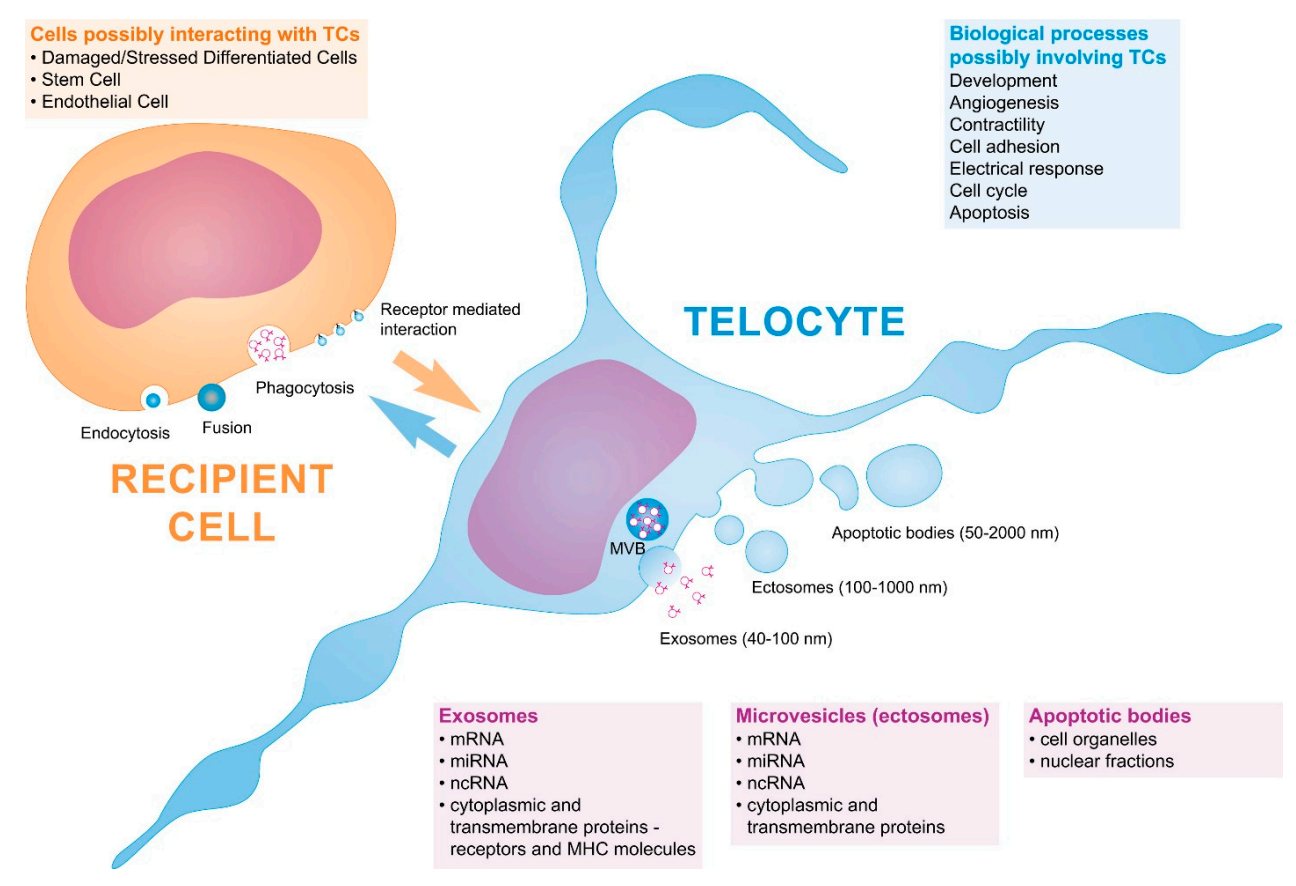

Figure 1. Schematic diagram of EVs transfer between cells, particularized for telocytes (TCs). Cells produce three types of extracellular vesicles (EVs): exosomes, ectosomes, and apoptotic bodies. The vesicles may be endocytosed, might fuse directly with the plasma membrane, or determine biological processes by ligand-receptor interactions on the cell surface. Arrows are indicative of the fact that the transfer is bidirectional and that EVs can shuttle between cells to communicate and exchange genetic material. Depending on the site of biogenesis, EVs' heterogeneity, size, and composition are slightly different. ncRNA: non-coding RNA; miRNA: microRNA; MVB: multivesicular body.

The presence of EVs has been reported in interstitial spaces and in all biological fluids, including plasma, saliva, urine, cerebrospinal fluid, sputum, bronchial lavage fluid, malignant ascites, amniotic fluid, breast milk, and seminal fluid [7-10]. EVs were also detected as a heterogeneous population in the secretome from cells cultured in vitro, in conditioned media [11,12]. Protected by their external lipid bilayer, the content of EVs targets the recipient cells by three different mechanisms: direct fusion with their plasma membranes, receptor-mediated uptake, and endocytosis (phagocytosis) [13-15].

EVs have been found to have important roles in many important physiological processes, such as stem cell upkeep [16,17], tissue repair [18], immune surveillance [19] and vascular hemostasis [20]. Moreover, EVs seem to play an important role in several diseases, such as cancer, neurodegenerative, cardiovascular, and metabolic diseases [21-26].

Nowadays, the importance EVs in research is highlighted by the immense interest of the extracellular vesicle community, since EVs are considered as biomarkers, and also as drug, vaccine, and gene vector delivery tools in human diseases [27-29].

In this review, we summarize the recent research on the characterization of a new cell population within the stromal compartment, namely the telocytes (TCs). We also highlight the fact that TCs are able to release EVs, and we assess the research being carried out and the current progress examining the roles of these cells as communicating devices.

\section{Telocytes as a Particular Type of Interstitial Cells}

Telocytes (TCs) represent a recently-discovered cell population of the connective tissue (the stromal compartment forming the supportive framework of any organ) [30,31]. According to Popescu, 
their discoverer, the simplest description of TCs is cells with telopodes [32]. Telopodes are extremely long extensions (tens to hundreds of micrometers) which arise from the small cell body of TCs (Figure 2) [33]. Telopodes are characterized by a moniliform appearance in the bidimensional plane of ultrathin sections, with dilated portions called podoms and very thin regions named podomers (Figure 3). A three-dimensional perspective changes the first impression of telopodes, which appear to be long, flattened irregular veils and tubular structures with uneven caliber, because of irregular dilations corresponding to the podoms (Figure 4) [34,35].
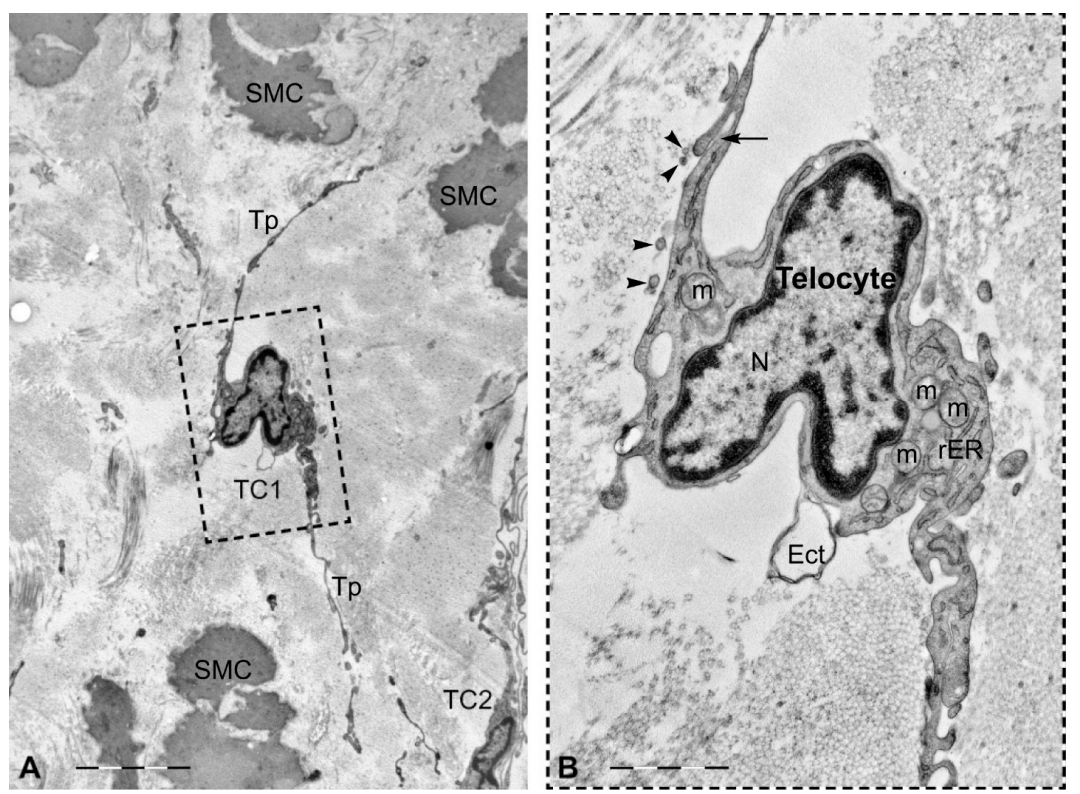

Figure 2. Transmission electron microscopy (TEM) of a telocyte in human non-pregnant myometrium. (A) Two cellular bodies (TC1, TC2) can be easily seen in the interstitial space between smooth myocytes. One telocyte has long, convoluting telopodes (TC2). Scale bar $=5 \mu \mathrm{m}$; (B) Higher magnification detail of the area marked with a dotted square in (A). Note that the heterochromatin is mostly confined to the periphery of the nucleus, but is also dispersed throughout. Scale bar $=1.5 \mu \mathrm{m}$. TC: telocyte; Tp: telopode; SMC: smooth muscle cell; $\mathrm{m}$ : mitochondrion; rER: rough endoplasmic reticulum; $\mathrm{N}$ : nucleus; arrowhead: exosome; Ect: ectosome; arrow: cellular junction.

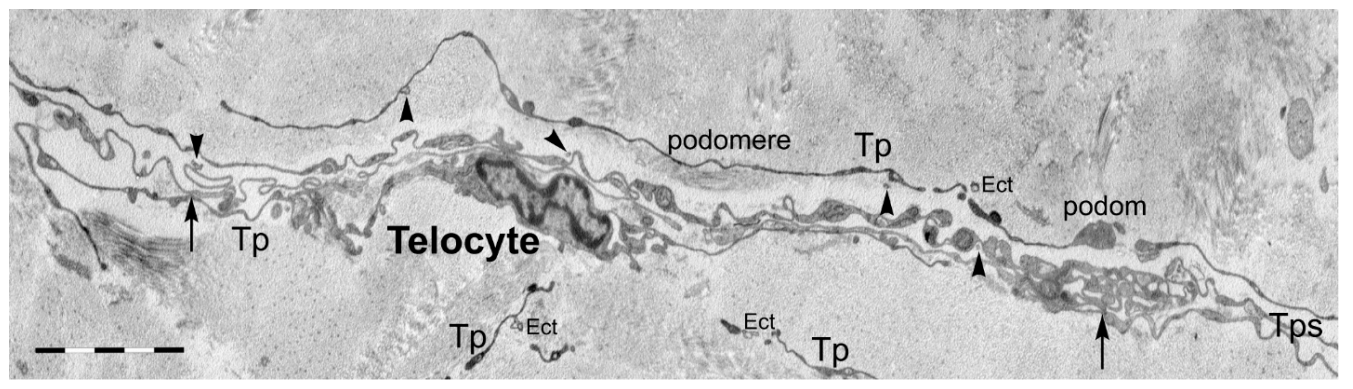

Figure 3. Transmission electron microscopy (TEM) of a telocyte in human non-pregnant myometrium. Image obtained by concatenation of seven microscopic fields. The telocyte exhibits a spindle-shape cell body, from where two extremely long telopodes are emerging. In the close proximity, other telopodes with tortuous trajectories contact the central telocyte by homo-cellular junctions, creating an intricate network. One can also observe numerous extracellular vesicles (arrowheads: exosomes; Ect: ectosomes) either shedding from or surrounding the telopodes. Arrows: cellular junctions; $\mathrm{Tp}(\mathrm{s})=$ telopode(s). Scale bar $=5 \mu \mathrm{m}$. 

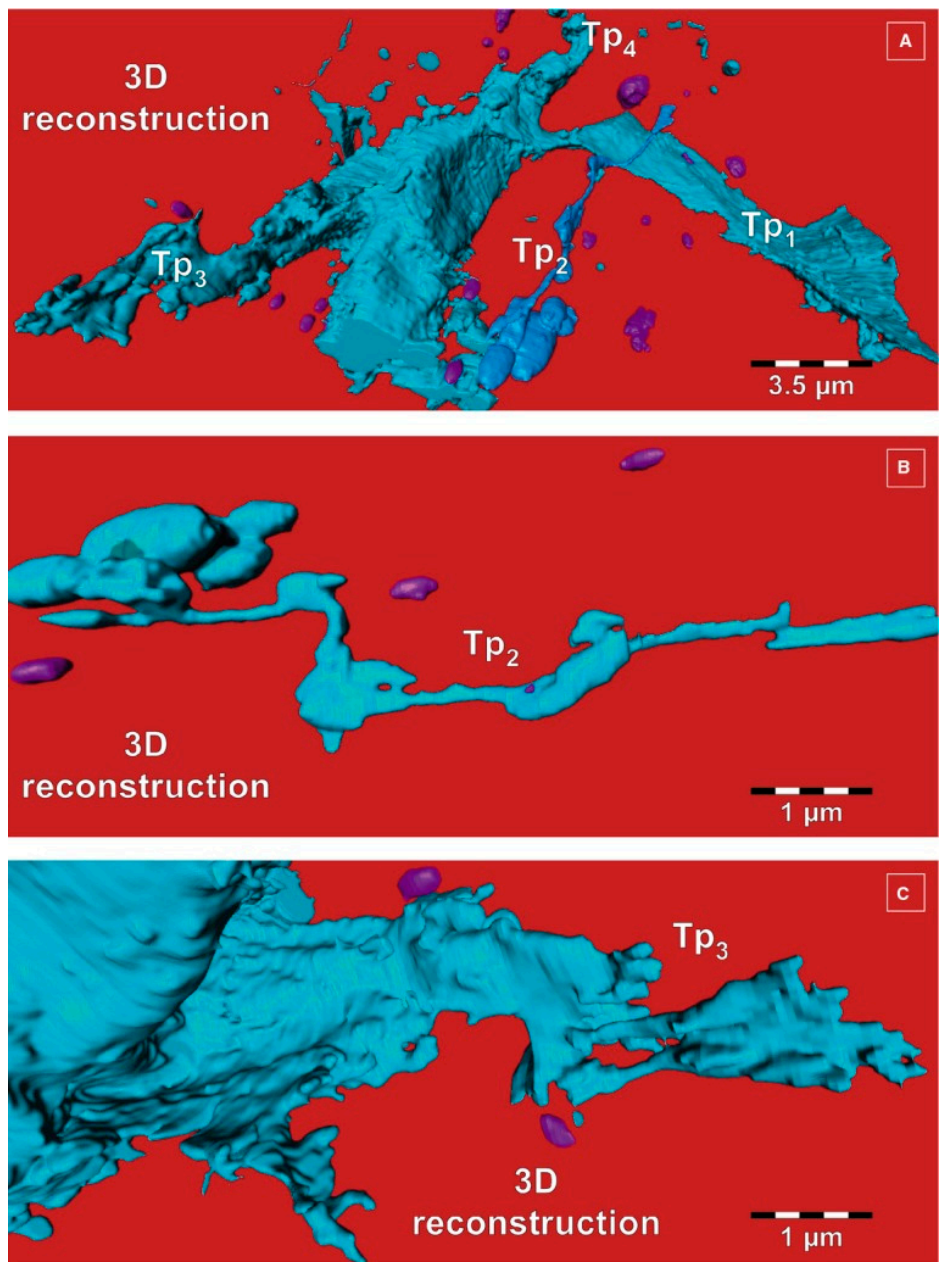

Figure 4. Focused ion beam scanning electron microscope (FIB-SEM) tomography. Three-dimensional reconstruction details of telopodes (Tps), from different viewing angles. (A) From this angle, four telopodes can be seen; (B) Tp2 has enlarged segments (podoms) alternating with slender segments; (C) Telopode with anfractuous contour. Extracellular vesicles appear in purple. Reproduced with permission from [35].

Telocytes are nowadays seen as connecting devices, since numerous papers describe their ability to interact with themselves by homocellular junctions and with other cell types by heterocellular junctions (for details see review [36]). In addition, TCs also contact-directly or at a certain distance-important surrounding structures, such as blood vessels, nerve endings, smooth muscles, glandular elements, and covering epithelia $[37,38]$.

Telocytes are functionally distinct from mesenchymal stem cells and fibroblasts with regard to their gene expression profile, and might have specific roles in cell signaling, tissue homeostasis, remodeling, and angiogenesis [39]. Chromosomal analysis also revealed that specific genes in lung TCs are different from those of pneumocytes, airway cells, mesenchymal stem cells, and lymphocytes [40-44]. Recently, TCs were characterized with the aid of various omics technologies such as mass spectrometry and multiplexed assays [45-47]. Several proteins were found to be up-regulated in TCs' proteome-e.g., mitochondrial thioredoxin-dependent peroxide reductase, protein disulphide-isomerase A3, myosin-14, myosin-10, filamin-B, sodium/potassium-transporting ATPase subunit $\alpha-1$ and keratin, type II cytoskeletal 1 . These proteins are also regularly found in the proteome of mammalian extracellular vesicles, and therefore it has been proposed that TCs are involved in extracellular environment homeostasis, possibly influencing stem cell niches and leading to cell differentiation [47]. 


\section{Telocytes and the Horizontal Transfer of Information}

Telocytes—formerly known as interstitial Cajal-like cells (ICLC)—were shown to release EVs. Mandache et al. showed the presence of such vesicles soon after the first detailed ultrastructural characterization of ICLC [48]. Since that early study, which suggested the existence of a paracrine and/or juxtacrine intercellular mutual modulation between these special cells and the surrounding cells, much interest was dedicated to this type of intercellular communication. In the stromal space of different organs, other studies revealed the existence of EVs derived from the cellular body of TCs and also from their telopodes [38,49-51]. In addition, a morphometric comparison was performed between extracellular membranous vesicles (exosomes and shedding microvesicles) found in human non-pregnant and pregnant uterus [52]. In these two physiological conditions, exosome release seemed to be more pronounced in pregnancy, suggesting a horizontal transfer of important macromolecules among neighboring cells [52]. Telocytes have been shown to be implicated in a variety of human pathologies (as reviewed in [53]), where they are significantly reduced and altered. Therefore, we can consider that the release of EVs might also be affected in this context through altered intercellular signaling. Additionally, as based on their different immunohistochemical subtypes (suggesting organ-specific phenotypes of TCs [54,55]), their local and distal microcommunication mechanisms might also be diverse, including the content of the EVs.

The release of EVs by TCs has also been demonstrated in vitro with the aid of electron microscopy and electron tomography. Fertig et al. described that cardiac TCs in culture release exosomes $(45 \pm 8 \mathrm{~nm}$ ), ectosomes (128 $\pm 28 \mathrm{~nm}$ ), and multivesicular cargos (MVC; $1 \pm 0.4 \mu \mathrm{m})$ [56]. To gain insight into the third dimension of the arborescent conformation of TCs, focused ion beam scanning electron microscope (FIB-SEM) tomography was recently used to highlight human skin TCs. The 3D analysis of the reconstructed ultrastructural volume depicted the biological fine structure of some EVs (diameter $438.6 \pm 149.1 \mathrm{~nm}, n=30$ ) at high resolution (Figure 5) [35]. The budding phenomenon was caught in progress, and represents valuable data about the three-dimensional morphology of telopodes and their capability to furnish extracellular vesicles at nanoscale dimensions (Figure 6).
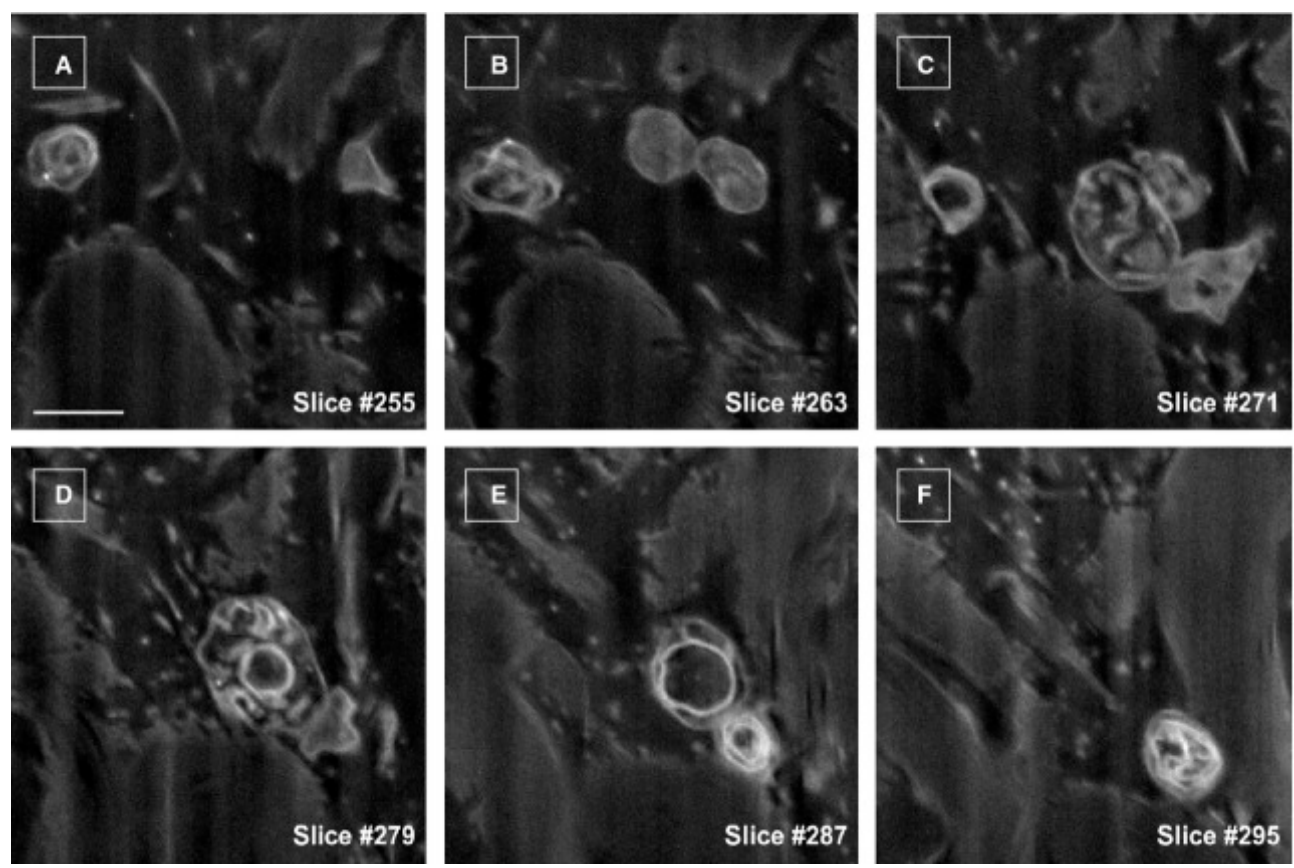

Figure 5. FIB-SEM of extracellular vesicle dynamics around a telocyte. (A-F) Six non-consecutive serial images depicting the biological fine structure of some EVs. Scale bar is $0.5 \mu \mathrm{m}$. Reproduced with permission from [35]. 

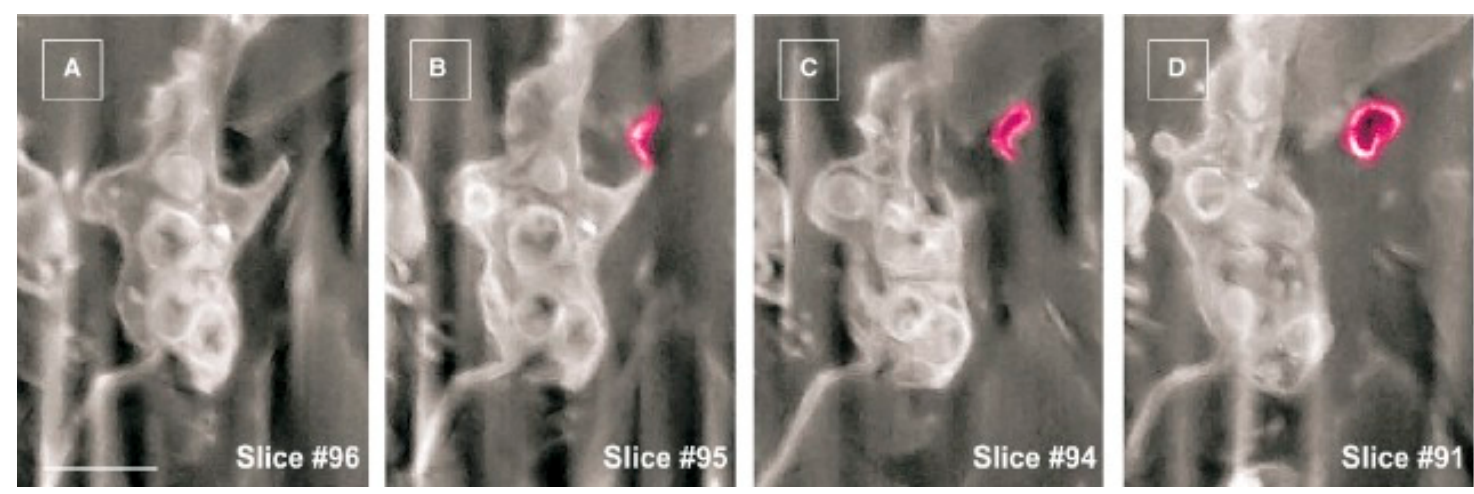

Figure 6. (A-D) FIB-SEM serial images of a human dermal telocyte presenting an extracellular vesicle (purple) budding from a podom. Note the empty appearance of the vesicle. Scale bar is $0.5 \mu \mathrm{m}$. Reproduced with permission from [35].

It is known that the transfer of microRNA is mediated by EVs, which function as effective delivery vehicles. In fact, it has been shown that EVs are enriched in miRNAs and that secreted miRNAs are protected by the membrane structures of EVs [57,58]. Several miRNAs were reported as associated or not with TCs. In an effort to identify a biomarker for the identification of TCs, it has been demonstrated that the lack of miR-193 expression differentiates microdissected TCs from other stromal cells (3T3 fibroblasts) in cell culture. Moreover, they do not express any of the cardiomyocyte-specific miRNAs (miRs) (miR-1, 133a, or 208a). Instead, various levels of miR-21, 22, 29, and 199a-5p were detected, in accordance with TCs' mesenchymal origin [59].

Recently, additional evidence has accumulated (in vivo and in vitro) about the importance of EVs in accomplishing the role of TCs in intercellular communication. Cismasiu and Popescu demonstrated the microRNA exchange between TCs and cardiac stem cells in cell cultures, when the EVs released from TCs are taken up by cardiac stem cells via endocytosis [60]. Furthermore, they demonstrated that cardiac stem cells deliver microRNA-loaded EVs to TCs, and suggested that "there is a continuous, post-transcriptional regulatory signal back and forth between TCs and stem cells" [60]. Several miRNAs with pro-angiopoietic potential ( $\mathrm{miR}-126$, miR-130, let-7e, and $\mathrm{miR}-100)$ were found to be expressed by TCs, and, moreover, the level of expression is increased in the myocardium soon after acute myocardial infarction [60]. Several experiments also reported an association between TCs and cardiac stem cells, stressing the contribution of TCs to neo-angiogenesis, especially in the infarcted myocardium $[45,61,62]$. This might also explain why cardiac TCs were found to be significantly increased in exercised heart, where they might contribute to cardiac renewal and regeneration [63]. The participation of TCs in angiogenesis is likely possible, since human lung telocytes could produce soluble factors such as VEGF and EGF, and were shown to induce the proliferation of pulmonary endothelial cells in cell cultures [64]. In a recent study, Li et al. [65] showed that both vascular TCs and vascular smooth muscle cells express miR-24, but the expression level of miR-24 is higher in TCs. Whether or not this miRNA is a cargo of the EVs and directly responsible for the effect remains to be established, but what is certain is that the supernatant of TCs in culture promoted the proliferation of vascular smooth muscle cells. Some other soluble factors in the supernatant-e.g., cytokines, including VEGF (vascular endothelial growth factor), IL-6 (interleukin-6), MIP-1 $\alpha$ (macrophage inflammatory protein 1- $\alpha$ ) might contribute to the repair process, too [45].

\section{Future Directions}

On one hand, there is a current growing interest in EVs is based on their physiological role in intercellular communication (especially in stem cell biology, where they can maintain the stemness capacity intervening in tissue repair) [66,67], and in pathological conditions (particularly in the pre-metastatic niche formation, cancer progression, and in the spread of numerous pathogens) [68-70]. 
On the other hand, the discovery of a new cell type known as telocytes, which are able to release EVs and interfere upon stem cells in their niches and upon other different somatic cells, allows us to speculate that they need special attention in the future. We need to learn more about the cargo in the EVs released by TCs, and if these vesicles are different in physiological and pathological conditions. Besides releasing vesicles, TCs were shown to have endocytic properties in the enteric wall (colon) and to participate in the uptake and storage of endogenous or exogenous particles in the skin and periodontal tissues (e.g., hemosiderin, melanin, and some components of dental amalgam). Therefore, Diaz-Flores et al. suggested that TCs are the principal non-macrophage cells with phagocytic-like properties [71]. As a consequence, one can consider that TCs represent important players in intercellular communication in between cells, locally or at a distance. A lot of information must be gathered before deciphering their precise role in physiological processes. In addition, TCs seem to change phenotype according to organ location [72-75], a phenomenon possibly explained by the different cargo in EVs and their shuttle trafficking between different cell types in response to diverse stimuli. Deciphering whether the content of EVs released/received by TCs is different according to location will open promising perspectives for controlling tissue homeostasis. It is possible that in the future we will be able to control the formation of telopodes [76], as well as the use of EVs as therapeutic potential agents.

As mentioned above, several hypotheses were raised about the functional roles of TCs; however, hardly any have been addressed to date. Although there are several papers discussing the interrelation between TCs and stem cells, the existing information about the involvement of TCs in cancer is scarce. Only two papers address this topic. Mirancea et al. [77] showed that TCs in normal dermis of the skin establish more heterocellular junctions in comparison with TCs of tumor dermis of basal cell carcinoma and squamous cell carcinoma, concluding that by decreasing their number of junctions, TCs might induce changes in intercellular communication into the peritumoral stroma and, consequently, into the whole tumor mass. Mou et al. stated that in situ "TCs communicate with breast cancer cells as well as other stromal cells, and might serve as a bridge that directly links the adjacent cells through membrane-to-membrane contact", while in experimental conditions of a reconstituted breast cancer "TCs and other breast stromal cells facilitated the formation of typical nest structure, promoted the proliferation of breast cancer cells, and inhibited their apoptosis" [78].

In conclusion, TCs are cells capable of acting as integrators of many intercellular functions; however, there is a long way ahead until their functional capabilities are elucidated. Moreover, the specific cargo for their EVs must be characterized, and the biodistribution of these vesicles also remains to be established. TCs are seen by different groups as future targets with implications for regenerative medicine [79-81].

Acknowledgments: This work was supported by grants from the Romanian National Authority for Scientific Research, CNCS-UEFISCDI, PNII projects number 82/2012 (for Sanda M. Cretoiu) and 194/2014 (for Dragos Cretoiu). This work was supported by Grants from the National Natural Science Foundation of China 81570362 (for Junjie Xiao) and 81270314 (for Jiahong Xu) and Shanghai Medical Guide Project from Shanghai Science and Technology Committee 134119a3000 (for Jiahong Xu).

Author Contributions: All authors contributed to the design, concepts and writing of this review. All authors read and approved the final manuscript.

Conflicts of Interest: The authors declare no conflict of interest.

\section{References}

1. Ratajczak, J.; Wysoczynski, M.; Hayek, F.; Janowska-Wieczorek, A.; Ratajczak, M.Z. Membrane-derived microvesicles: Important and underappreciated mediators of cell-to-cell communication. Leukemia 2006, 20, 1487-1495. [CrossRef] [PubMed]

2. Camussi, G.; Deregibus, M.C.; Bruno, S.; Cantaluppi, V.; Biancone, L. Exosomes/microvesicles as a mechanism of cell-to-cell communication. Kidney Int. 2010, 78, 838-848. [CrossRef] [PubMed] 
3. Johnstone, R.M.; Adam, M.; Hammond, J.R.; Orr, L.; Turbide, C. Vesicle formation during reticulocyte maturation. Association of plasma membrane activities with released vesicles (exosomes). J. Biol. Chem. 1987, 262, 9412-9420. [PubMed]

4. Andaloussi, S.E.L.; Mager, I.; Breakefield, X.O.; Wood, M.J. Extracellular vesicles: Biology and emerging therapeutic opportunities. Nat. Rev. Drug Discov. 2013, 12, 347-357. [CrossRef] [PubMed]

5. Heijnen, H.F.; Schiel, A.E.; Fijnheer, R.; Geuze, H.J.; Sixma, J.J. Activated platelets release two types of membrane vesicles: Microvesicles by surface shedding and exosomes derived from exocytosis of multivesicular bodies and $\alpha$-granules. Blood 1999, 94, 3791-3799. [PubMed]

6. Mora, E.M.; Alvarez-Cubela, S.; Oltra, E. Biobanking of exosomes in the era of precision medicine: Are we there yet? Int. J. Mol. Sci. 2016, 17, 13. [CrossRef] [PubMed]

7. Lasser, C.; Alikhani, V.S.; Ekstrom, K.; Eldh, M.; Paredes, P.T.; Bossios, A.; Sjostrand, M.; Gabrielsson, S.; Lotvall, J.; Valadi, H. Human saliva, plasma and breast milk exosomes contain rna: Uptake by macrophages. J. Transl. Med. 2011, 9, 9. [CrossRef] [PubMed]

8. McDonald, M.K.; Capasso, K.E.; Ajit, S.K. Purification and microrna profiling of exosomes derived from blood and culture media. J. Vis. Exp. 2013, 70, e50294. [CrossRef] [PubMed]

9. Keller, S.; Ridinger, J.; Rupp, A.K.; Janssen, J.W.; Altevogt, P. Body fluid derived exosomes as a novel template for clinical diagnostics. J. Transl. Med. 2011, 9. [CrossRef] [PubMed]

10. Machida, T.; Tomofuji, T.; Ekuni, D.; Maruyama, T.; Yoneda, T.; Kawabata, Y.; Mizuno, H.; Miyai, H.; Kunitomo, M.; Morita, M. Micrornas in salivary exosome as potential biomarkers of aging. Int. J. Mol. Sci. 2015, 16, 21294-21309. [CrossRef] [PubMed]

11. Pasalic, L.; Williams, R.; Siupa, A.; Campbell, H.; Henderson, M.J.; Chen, V.M. Enumeration of extracellular vesicles by a new improved flow cytometric method is comparable to fluorescence mode nanoparticle tracking analysis. Nanomed. Nanotechnol. Biol. Med. 2016, 12, 977-986. [CrossRef] [PubMed]

12. Rosas, L.E.; Elgamal, O.A.; Mo, X.; Phelps, M.A.; Schmittgen, T.D.; Papenfuss, T.L. In vitro immunotoxicity assessment of culture-derived extracellular vesicles in human monocytes. J. Immunotoxicol. 2016, 1-14. [CrossRef]

13. Mulcahy, L.A.; Pink, R.C.; Carter, D.R. Routes and mechanisms of extracellular vesicle uptake. J. Extracell. Vesicles 2014, 3. [CrossRef] [PubMed]

14. Urbanelli, L.; Magini, A.; Buratta, S.; Brozzi, A.; Sagini, K.; Polchi, A.; Tancini, B.; Emiliani, C. Signaling pathways in exosomes biogenesis, secretion and fate. Genes 2013, 4, 152-170. [CrossRef] [PubMed]

15. Villarroya-Beltri, C.; Baixauli, F.; Gutierrez-Vazquez, C.; Sanchez-Madrid, F.; Mittelbrunn, M. Sorting it out: Regulation of exosome loading. Semin. Cancer Biol. 2014, 28, 3-13. [CrossRef] [PubMed]

16. Ratajczak, J.; Miekus, K.; Kucia, M.; Zhang, J.; Reca, R.; Dvorak, P.; Ratajczak, M.Z. Embryonic stem cell-derived microvesicles reprogram hematopoietic progenitors: Evidence for horizontal transfer of mRNA and protein delivery. Leukemia 2006, 20, 847-856. [CrossRef] [PubMed]

17. Han, C.; Sun, X.; Liu, L.; Jiang, H.; Shen, Y.; Xu, X.; Li, J.; Zhang, G.; Huang, J.; Lin, Z.; et al. Exosomes and their therapeutic potentials of stem cells. Stem Cells Int. 2016, 2016, 7653489. [CrossRef] [PubMed]

18. Ratajczak, M.Z.; Kucia, M.; Jadczyk, T.; Greco, N.J.; Wojakowski, W.; Tendera, M.; Ratajczak, J. Pivotal role of paracrine effects in stem cell therapies in regenerative medicine: Can we translate stem cell-secreted paracrine factors and microvesicles into better therapeutic strategies? Leukemia 2012, 26, 1166-1173. [CrossRef] [PubMed]

19. Lugini, L.; Cecchetti, S.; Huber, V.; Luciani, F.; Macchia, G.; Spadaro, F.; Paris, L.; Abalsamo, L.; Colone, M.; Molinari, A.; et al. Immune surveillance properties of human NK cell-derived exosomes. J. Immunol. 2012, 189, 2833-2842. [CrossRef] [PubMed]

20. Lacroix, R.; Dignat-George, F. Microparticles as a circulating source of procoagulant and fibrinolytic activities in the circulation. Thromb. Res. 2012, 129, S27-S29. [CrossRef] [PubMed]

21. Roma-Rodrigues, C.; Fernandes, A.R.; Baptista, P.V. Exosome in tumour microenvironment: Overview of the crosstalk between normal and cancer cells. Biomed. Res. Int. 2014, 2014, 179486. [CrossRef] [PubMed]

22. Shi, M.; Liu, C.; Cook, T.J.; Bullock, K.M.; Zhao, Y.; Ginghina, C.; Li, Y.; Aro, P.; Dator, R.; He, C.; et al. Plasma exosomal alpha-synuclein is likely CNS-derived and increased in Parkinson's disease. Acta Neuropathol. 2014, 128, 639-650. [CrossRef] [PubMed] 
23. Fiandaca, M.S.; Kapogiannis, D.; Mapstone, M.; Boxer, A.; Eitan, E.; Schwartz, J.B.; Abner, E.L.; Petersen, R.C.; Federoff, H.J.; Miller, B.L.; et al. Identification of preclinical Alzheimer's disease by a profile of pathogenic proteins in neurally derived blood exosomes: A case-control study. Alzheimer's Dement. 2015, 11, $600-607$. [CrossRef] [PubMed]

24. Stern, R.A.; Tripodis, Y.; Baugh, C.M.; Fritts, N.G.; Martin, B.M.; Chaisson, C.; Cantu, R.C.; Joyce, J.A.; Shah, S.; Ikezu, T.; et al. Preliminary study of plasma exosomal tau as a potential biomarker for chronic traumatic encephalopathy. J. Alzheimer's Dis. 2016, 51, 1099-1109. [CrossRef] [PubMed]

25. Aikawa, E. Extracellular vesicles in cardiovascular disease: Focus on vascular calcification. J. Physiol. 2016, 594, 2877-2880. [CrossRef] [PubMed]

26. Osteikoetxea, X.; Nemeth, A.; Sodar, B.W.; Vukman, K.V.; Buzas, E.I. Extracellular vesicles in cardiovascular disease: Are they Jedi or Sith? J. Physiol. 2016, 594, 2881-2894. [CrossRef] [PubMed]

27. Zhang, B.; Yeo, R.W.; Tan, K.H.; Lim, S.K. Focus on extracellular vesicles: Therapeutic potential of stem cell-derived extracellular vesicles. Int. J. Mol. Sci. 2016, 17, 174. [CrossRef] [PubMed]

28. Batrakova, E.V.; Kim, M.S. Using exosomes, naturally-equipped nanocarriers, for drug delivery. J. Control. Release 2015, 219, 396-405. [CrossRef] [PubMed]

29. Ren, J.; He, W.; Zheng, L.; Duan, H. From structures to functions: Insights into exosomes as promising drug delivery vehicles. Biomater. Sci. 2016, 4, 910-921. [CrossRef] [PubMed]

30. Popescu, L.M.; Faussone-Pellegrini, M.S. Telocytes-A case of serendipity: The winding way from interstitial cells of Cajal (ICC), via interstitial Cajal-like cells (ICLC) to telocytes. J. Cell. Mol. Med. 2010, 14, 729-740. [CrossRef] [PubMed]

31. Cretoiu, S.M.; Popescu, L.M. Telocytes revisited. Biomol. Concepts 2014, 5, 353-369. [CrossRef] [PubMed]

32. Popescu, L.M. Telocytes-A novel type of interstitial cells. In Recent Researches in Modern Medicine; Braissant, O., Wakamatsu, H., Kuo-Kang, I., Allegaert, K., Lenbury, Y., Wachholtz, A., Eds.; WSEAS Press: Cambridge, UK, 2011; pp. 424-432.

33. Roatesi, I.; Radu, B.M.; Cretoiu, D.; Cretoiu, S.M. Uterine telocytes: A review of current knowledge. Biol. Reprod. 2015, 93. [CrossRef] [PubMed]

34. Cretoiu, D.; Hummel, E.; Zimmermann, H.; Gherghiceanu, M.; Popescu, L.M. Human cardiac telocytes: 3D imaging by fib-sem tomography. J. Cell. Mol. Med. 2014, 18, 2157-2164. [CrossRef] [PubMed]

35. Cretoiu, D.; Gherghiceanu, M.; Hummel, E.; Zimmermann, H.; Simionescu, O.; Popescu, L.M. Fib-sem tomography of human skin telocytes and their extracellular vesicles. J. Cell. Mol. Med. 2015, 19, 714-722. [CrossRef] [PubMed]

36. Faussone-Pellegrini, M.S.; Gherghiceanu, M. Telocyte's contacts. Semin. Cell Dev. Biol. 2016, 55, 3-8. [CrossRef] [PubMed]

37. Cretoiu, D.; Cretoiu, S.M.; Simionescu, A.A.; Popescu, L.M. Telocytes, a distinct type of cell among the stromal cells present in the lamina propria of jejunum. Histol. Histopathol. 2012, 27, 1067-1078. [PubMed]

38. Cretoiu, S.M.; Cretoiu, D.; Popescu, L.M. Human myometrium-The ultrastructural 3D network of telocytes. J. Cell. Mol. Med. 2012, 16, 2844-2849. [CrossRef] [PubMed]

39. Zheng, Y.; Zhang, M.; Qian, M.; Wang, L.; Cismasiu, V.B.; Bai, C.; Popescu, L.M.; Wang, X. Genetic comparison of mouse lung telocytes with mesenchymal stem cells and fibroblasts. J. Cell. Mol. Med. 2013, 17, 567-577. [CrossRef] [PubMed]

40. Sun, X.; Zheng, M.; Zhang, M.; Qian, M.; Zheng, Y.; Li, M.; Cretoiu, D.; Chen, C.; Chen, L.; Popescu, L.M.; et al. Differences in the expression of chromosome 1 genes between lung telocytes and other cells: Mesenchymal stem cells, fibroblasts, alveolar type II cells, airway epithelial cells and lymphocytes. J. Cell. Mol. Med. 2014, 18, 801-810. [CrossRef] [PubMed]

41. Zheng, M.; Sun, X.; Zhang, M.; Qian, M.; Zheng, Y.; Li, M.; Cretoiu, S.M.; Chen, C.; Chen, L.; Cretoiu, D.; et al. Variations of chromosomes 2 and 3 gene expression profiles among pulmonary telocytes, pneumocytes, airway cells, mesenchymal stem cells and lymphocytes. J. Cell. Mol. Med. 2014, 18, 2044-2060. [CrossRef] [PubMed]

42. Song, D.; Cretoiu, D.; Zheng, M.; Qian, M.; Zhang, M.; Cretoiu, S.M.; Chen, L.; Fang, H.; Popescu, L.M.; Wang, X. Comparison of chromosome 4 gene expression profile between lung telocytes and other local cell types. J. Cell. Mol. Med. 2016, 20, 71-80. [CrossRef] [PubMed] 
43. Wang, J.; Ye, L.; Jin, M.; Wang, X. Global analyses of chromosome 17 and 18 genes of lung telocytes compared with mesenchymal stem cells, fibroblasts, alveolar type ii cells, airway epithelial cells, and lymphocytes. Biol. Direct 2015, 10, 9. [CrossRef] [PubMed]

44. Zhu, Y.; Zheng, M.; Song, D.; Ye, L.; Wang, X. Global comparison of chromosome x genes of pulmonary telocytes with mesenchymal stem cells, fibroblasts, alveolar type II cells, airway epithelial cells, and lymphocytes. J. Transl. Med. 2015, 13. [CrossRef] [PubMed]

45. Albulescu, R.; Tanase, C.; Codrici, E.; Popescu, D.I.; Cretoiu, S.M.; Popescu, L.M. The secretome of myocardial telocytes modulates the activity of cardiac stem cells. J. Cell. Mol. Med. 2015, 19, 1783-1794. [CrossRef] [PubMed]

46. Zheng, Y.; Cretoiu, D.; Yan, G.; Cretoiu, S.M.; Popescu, L.M.; Fang, H.; Wang, X. Protein profiling of human lung telocytes and microvascular endothelial cells using iTRAQ quantitative proteomics. J. Cell. Mol. Med. 2014, 18, 1035-1059. [CrossRef] [PubMed]

47. Zheng, Y.; Cretoiu, D.; Yan, G.; Cretoiu, S.M.; Popescu, L.M.; Wang, X. Comparative proteomic analysis of human lung telocytes with fibroblasts. J. Cell. Mol. Med. 2014, 18, 568-589. [CrossRef] [PubMed]

48. Mandache, E.; Popescu, L.M.; Gherghiceanu, M. Myocardial interstitial Cajal-like cells (ICLC) and their nanostructural relationships with intercalated discs: Shed vesicles as intermediates. J. Cell. Mol. Med. 2007, 11, 1175-1184. [CrossRef] [PubMed]

49. Popescu, L.M.; Manole, E.; Serboiu, C.S.; Manole, C.G.; Suciu, L.C.; Gherghiceanu, M.; Popescu, B.O. Identification of telocytes in skeletal muscle interstitium: Implication for muscle regeneration. J. Cell. Mol. Med. 2011, 15, 1379-1392. [CrossRef] [PubMed]

50. Nicolescu, M.I.; Bucur, A.; Dinca, O.; Rusu, M.C.; Popescu, L.M. Telocytes in parotid glands. Anat. Rec. 2012, 295, 378-385. [CrossRef] [PubMed]

51. Nicolescu, M.I.; Popescu, L.M. Telocytes in the interstitium of human exocrine pancreas: Ultrastructural evidence. Pancreas 2012, 41, 949-956. [CrossRef] [PubMed]

52. Cretoiu, S.M.; Cretoiu, D.; Marin, A.; Radu, B.M.; Popescu, L.M. Telocytes: Ultrastructural, immunohistochemical and electrophysiological characteristics in human myometrium. Reproduction 2013, 145, 357-370. [CrossRef] [PubMed]

53. Ibba-Manneschi, L.; Rosa, I.; Manetti, M. Telocyte implications in human pathology: An overview. Semin. Cell Dev. Biol. 2016, 55, 62-69. [CrossRef] [PubMed]

54. Diaz-Flores, L.; Gutierrez, R.; Diaz-Flores, L., Jr.; Gomez, M.G.; Saez, F.J.; Madrid, J.F. Behaviour of telocytes during physiopathological activation. Semin. Cell Dev. Biol. 2016, 55, 50-61. [CrossRef] [PubMed]

55. Chang, Y.; Li, C.; Lu, Z.; Li, H.; Guo, Z. Multiple immunophenotypes of cardiac telocytes. Exp. Cell Res. 2015, 338, 239-244. [CrossRef] [PubMed]

56. Fertig, E.T.; Gherghiceanu, M.; Popescu, L.M. Extracellular vesicles release by cardiac telocytes: Electron microscopy and electron tomography. J. Cell. Mol. Med. 2014, 18, 1938-1943. [CrossRef] [PubMed]

57. Kosaka, N.; Iguchi, H.; Yoshioka, Y.; Takeshita, F.; Matsuki, Y.; Ochiya, T. Secretory mechanisms and intercellular transfer of microRNAs in living cells. J. Biol. Chem. 2010, 285, 17442-17452. [CrossRef] [PubMed]

58. Ahmed, K.A.; Xiang, J. Mechanisms of cellular communication through intercellular protein transfer. J. Cell. Mol. Med. 2011, 15, 1458-1473. [CrossRef] [PubMed]

59. Cismasiu, V.B.; Radu, E.; Popescu, L.M. Mir-193 expression differentiates telocytes from other stromal cells. J. Cell. Mol. Med. 2011, 15, 1071-1074. [CrossRef] [PubMed]

60. Cismasiu, V.B.; Popescu, L.M. Telocytes transfer extracellular vesicles loaded with micrornas to stem cells. J. Cell. Mol. Med. 2015, 19, 351-358. [CrossRef] [PubMed]

61. Zhao, B.; Liao, Z.; Chen, S.; Yuan, Z.; Yilin, C.; Lee, K.K.; Qi, X.; Shen, X.; Zheng, X.; Quinn, T.; et al. Intramyocardial transplantation of cardiac telocytes decreases myocardial infarction and improves post-infarcted cardiac function in rats. J. Cell. Mol. Med. 2014, 18, 780-789. [CrossRef] [PubMed]

62. Ja, K.P.; Miao, Q.; Tee, Z.; Nicole, G.; Lim, S.Y.; Nandihalli, M.; JA Ramachandra, C.; Mehta, A.; Shim, W. Ipsc-derived human cardiac progenitor cells improve ventricular remodelling via angiogenesis and interstitial networking of infarcted myocardium. J. Cell. Mol. Med. 2016, 20, 323-332. [CrossRef] [PubMed]

63. Xiao, J.; Chen, P.; Qu, Y.; Yu, P.; Yao, J.; Wang, H.; Fu, S.; Bei, Y.; Chen, Y.; Che, L.; et al. Telocytes in exercise-induced cardiac growth. J. Cell. Mol. Med. 2016, 20, 973-979. [CrossRef] [PubMed] 
64. Zheng, Y.; Chen, X.; Qian, M.; Zhang, M.; Zhang, D.; Bai, C.; Wang, Q.; Wang, X. Human lung telocytes could promote the proliferation and angiogenesis of human pulmonary microvascular endothelial cells in vitro. Mol. Cell. Ther. 2014, 2. [CrossRef] [PubMed]

65. Li, Y.; Zhang, X.; Gao, J.; Xiao, H.; Xu, M. Increased telocytes involved in the proliferation of vascular smooth muscle cells in rat carotid artery balloon injury. Sci. China Life Sci. 2016. [CrossRef] [PubMed]

66. Katsman, D.; Stackpole, E.J.; Domin, D.R.; Farber, D.B. Embryonic stem cell-derived microvesicles induce gene expression changes in muller cells of the retina. PLOS ONE 2012, 7, e50417. [CrossRef] [PubMed]

67. Farber, D.B.; Katsman, D. Embryonic stem cell-derived microvesicles: Could they be used for retinal regeneration? Adv. Exp. Med. Biol. 2016, 854, 563-569. [PubMed]

68. Cao, Y.; Liu, C.; Gu, Z.; Zhang, Y.; Duan, Y.; Zhang, Y.; Zhang, H.; Tang, K.; Huang, B. Microparticles mediate human papillomavirus type 6 or 11 infection of human macrophages. Cell. Mol. Immunol. 2015. [CrossRef] [PubMed]

69. Woollard, S.M.; Li, H.; Singh, S.; Yu, F.; Kanmogne, G.D. HIV-1 induces cytoskeletal alterations and Rac1 activation during monocyte-blood-brain barrier interactions: Modulatory role of CCR5. Retrovirology 2014, 11. [CrossRef] [PubMed]

70. Peinado, H.; Aleckovic, M.; Lavotshkin, S.; Matei, I.; Costa-Silva, B.; Moreno-Bueno, G.; Hergueta-Redondo, M.; Williams, C.; Garcia-Santos, G.; Ghajar, C.; et al. Melanoma exosomes educate bone marrow progenitor cells toward a pro-metastatic phenotype through met. Nat. Med. 2012, 18, 883-891. [CrossRef] [PubMed]

71. Diaz-Flores, L.; Gutierrez, R.; Garcia, M.P.; Saez, F.J.; Aparicio, F.; Diaz-Flores, L., Jr.; Madrid, J.F. Uptake and intracytoplasmic storage of pigmented particles by human CD34+ stromal cells/telocytes: Endocytic property of telocytes. J. Cell. Mol. Med. 2014, 18, 2478-2487. [CrossRef] [PubMed]

72. Diaz-Flores, L.; Gutierrez, R.; Garcia, M.P.; Gonzalez, M.; Saez, F.J.; Aparicio, F.; Diaz-Flores, L., Jr.; Madrid, J.F. Human resident CD34+ stromal cells/telocytes have progenitor capacity and are a source of $\alpha \mathrm{SMA}+$ cells during repair. Histol. Histopathol. 2015, 30, 615-627. [PubMed]

73. Diaz-Flores, L.; Gutierrez, R.; Garcia, M.P.; Saez, F.J.; Diaz-Flores, L., Jr.; Valladares, F.; Madrid, J.F. CD34+ stromal cells/fibroblasts/fibrocytes/telocytes as a tissue reserve and a principal source of mesenchymal cells. Location, morphology, function and role in pathology. Histol. Histopathol. 2014, 29, 831-870. [PubMed]

74. Cretoiu, D.; Cretoiu, S.M. Telocytes in the reproductive organs: Current understanding and future challenges. Semin. Cell Dev. Biol. 2016, 55, 40-49. [CrossRef] [PubMed]

75. Cretoiu, S.M. Immunohistochemistry of telocytes in uterus and fallopian tubes. In Telocytes: Connecting Cells; Wang, X., Cretoiu, D., Eds.; Springer: Beijing, China, 2016.

76. Campeanu, R.A.; Radu, B.M.; Cretoiu, S.M.; Banciu, D.D.; Banciu, A.; Cretoiu, D.; Popescu, L.M. Near-infrared low-level laser stimulation of telocytes from human myometrium. Lasers Med. Sci. 2014, 29, 1867-1874. [CrossRef] [PubMed]

77. Mirancea, N.; Morosanu, A.M.; Mirancea, G.V.; Juravle, F.D.; Manoiu, V.S. Infrastructure of the telocytes from tumor stroma in the skin basal and squamous cell carcinomas. Rom. J. Morphol. Embryol. Rev. Roum. Morphol. Embryol. 2013, 54, 1025-1037.

78. Mou, Y.; Wang, Y.; Li, J.; Lu, S.; Duan, C.; Du, Z.; Yang, G.; Chen, W.; Zhao, S.; Zhou, J.; et al. Immunohistochemical characterization and functional identification of mammary gland telocytes in the self-assembly of reconstituted breast cancer tissue in vitro. J. Cell. Mol. Med. 2013, 17, 65-75. [CrossRef] [PubMed]

79. Horch, R.E.; Kneser, U.; Polykandriotis, E.; Schmidt, V.J.; Sun, J.; Arkudas, A. Tissue engineering and regenerative medicine-Where do we stand? J. Cell. Mol. Med. 2012, 16, 1157-1165. [CrossRef] [PubMed]

80. Boos, A.M.; Weigand, A.; Brodbeck, R.; Beier, J.P.; Arkudas, A.; Horch, R.E. The potential role of telocytes in tissue engineering and regenerative medicine. Semin. Cell Dev. Biol. 2016, 55, 70-78. [CrossRef] [PubMed]

81. Ratajczak, M.Z.; Ratajczak, J. Horizontal transfer of RNA and proteins between cells by extracellular microvesicles: 14 Years later. Clin. Transl. Med. 2016, 5. [CrossRef] [PubMed]

(C) 2016 by the authors; licensee MDPI, Basel, Switzerland. This article is an open access article distributed under the terms and conditions of the Creative Commons Attribution (CC-BY) license (http://creativecommons.org/licenses/by/4.0/). 